\title{
Effect of environmental and nutritional factors on growth and azaspiracid production of the dinoflagellate Azadinium spinosum
}

\author{
Thierry Jauffrais ${ }^{a, b}$, , Véronique Séchet ${ }^{a}$, Christine Herrenknecht ${ }^{b}$, Philippe Truquet ${ }^{a}$, \\ Savar Véronique ${ }^{a}$, Urban Tillmann ${ }^{c}$, Philipp Hess ${ }^{a, *}$ \\ ${ }^{a}$ IFREMER, Laboratoire EMP/PHYC, Rue de l'lle d'Yeu, 44311 Nantes, France \\ ${ }^{b}$ LUNAM, Université de Nantes, MMS EA2160, 2 rue de la Houssinière, 44035 Nantes, France \\ ${ }^{c}$ Alfred Wegener Institute, Am Handelshafen 12, D-27570 Bremerhaven, Germany \\ *: Corresponding authors : Thierry Jauffrais, email addresses : Thierry.Jauffrais@univ-nantes.fr ; \\ thierry.jauffrais@ifremer.fr ; Philipp Hess, email address : Philipp.Hess@ifremer.fr ; tel.: +33 240374257 ;
} fax: +33240374026

\begin{abstract}
:
Azadinium spinosum, a small dinoflagellate isolated from the North Sea, is a producer of azaspiracids (AZAs), a group of biotoxins associated with human illness following ingestion of contaminated shellfish. Using batch and continuous cultures of $A$. spinosum, the present study investigated the effects of different environmental and nutritional factors (salinity, temperature, photon flux density, aeration, culture media, nitrogen sources, phosphate source, and N/P ratios) on growth, maximum cell concentration, and AZA cell quota.
\end{abstract}

Azadinium spinosum grew in a wide range of conditions fro $1 \mathrm{C}$ to $6 \mathrm{C}$ and salinities from 30 to 40 , under irradiances ranging from $50 \mu \mathrm{mol} \mathrm{m}^{-} \mathrm{s}^{-1}$ to $250 \mu \mathrm{mol} \mathrm{m} \mathrm{s}^{-1}$, with or without aeration. Growth and maximum cell concentration were highest at a salinit of 35, at te peratures between $1 \mathrm{C}$ and $\mathrm{C}$, and with aeration Concerning cell quota, the ost significant effect was observed at low te perature the cell quota was ore than $\mathrm{ti}$ es higher at $1 \mathrm{C}\left(220 \mathrm{fg} \mathrm{cell}^{-1}\right.$ than at te peratures between $1 \mathrm{C}$ and 6 C. A. spinosum grew on all media tested with only slight differences in growth rate and AZA cell quota. In continuous culture, lowering the concentration of nutrients ( 0.5 strength of a modified K-medium) in the inflow improved AZA cell quota whereas higher concentration (doubling the normal strength of $\mathrm{K}$ medium) improved maximal cell concentration. A. spinosum grew on different sources of nitrogen tested (nitrate, urea, ammonium) with almost no effect on toxin cell quota and growth, except that adding ammonium caused a decrease in growth.

These first experiments on Azadinium spinosum increased our knowledge on factors affecting its growth and toxin production; furthermore, these results allowed and improved particularly $A$. spinosum production in pilot scale photobioreactors for AZA isolation.

Keywords: AZA ; Chemostat ; Dinophyceae ; Nutrients ; N/P ratio ; Photobioreactor

Highlights

Azadinium spinosum was exposed to different environmental and nutritional factors $\rightarrow$ Growth, biomass and AZA cell quota were observed in continuous and or batch culture $A$. spinosum grew in a wide range of conditions Temperature had the main effect on AZA cell quota. 


\section{Introduction}

Azadinium spinosum is a small dinoflagellate (12-16 $\mu \mathrm{m}$ length and 7-11 $\mu \mathrm{m}$ width) producing azaspiracid-1 and -2 (AZAs) (Tillmann et al., 2009). This dinoflagellate was first isolated from the North Sea off Scotland during a research cruise, with on-board LC-MS/MS to screen different size fractions of phytoplankton for the characterization and isolation of AZA producing organisms (Krock et al., 2008). Following its discovery, a new genus Azadinium was erected (Tillmann et al., 2009), which rapidly was expanded by the identification of other new species. These are $A$. obesum and $A$. polongum, which are not known to produce AZAs (Tillmann et al., 2010; Tillmann et al., 2012b), and $A$. poporum (Tillmann et al., 2011) including a strain designated as $A$. cf. poporum (Potvin et al., 2012) isolated from Korea and additional strains of $A$. poporum isolated from China (Gu et al., 2013). A. poporum has recently been found to produce AZAs, partly of a new type, which also was detected in Amphidoma languida (Krock et al., 2012) a species closely related to Azadinium (Tillmann et al., 2012a). Generally, A. poporum was shown to be quite variable in terms of AZA profile, with a number of the Chinese strains producing AZA-2 (Gu et al., 2013). Other strains of $A$. spinosum subsequently isolated in Denmark (Tillmann et al., 2011), Ireland (Salas et al., 2011), and from the Shetland Islands (Tillmann et al., 2012b) were all found to produce AZA1 and -2 and another AZA of a different mass, termed AZA-716 (Tillmann et al., 2012b). A species of Azadinium, described as A. cf. spinosum morphotype was reported from Argentina (Akselman and Negri, 2012). The authors reported a bloom (up to $9.03 \times 10^{6}$ cell L $^{-1}$ ) in 1990; however, intoxications following shellfish consumption were not reported at that time.

Concerning AZAs, the toxin was found 12 years before the primary producing organism. In 1995, contaminated mussels (Mytilus edulis) from Killary Harbour (Ireland) were consumed in the Netherlands and caused human illness (McMahon and Silke, 1996). The symptoms were diarrhea, nausea, vomiting and stomach cramp, typical for diarrheic shellfish poisoning (DSP). However, concentration of okadaic acid and analogues were below the regulatory limit. Subsequently, AZA1 was discovered (Satake et al., 1998) and later structurally revised (Nicolaou et al., 2006). The base structure of this toxin group is composed of an cyclic amine group (aza group), a tri-spiro ring assembly and a carboxylic acid group (Satake et al., 1998). Since its identification, the toxin was found to be responsible for additional human intoxications in Europe (Furey et al., 2010) and in the US (Klontz et al., 2009). AZAs were identified throughout Northern and Western Europe (Amzil et al., 2008; James et al., 2002; Magdalena et al., 2003; Vale et al., 2008) and in Morocco (Taleb et al., 2006), Chile (LopezRivera et al., 2009), Japan (Ueoka et al., 2009), and China (Yao et al., 2010), indicating a worldwide distribution of the toxin and consequently of the producing organism.

In feeding experiments, $A$. spinosum was found to directly contaminate mussels, with a fast AZA accumulation and biotransformation after a day or more of exposure to $A$. spinosum (Jauffrais et al., 2012c; Salas et al., 2011). In spite of the importance of $A$. spinosum as an AZA producer, little is known on factors affecting $A$. spinosum physiological responses in terms of growth, cell yield and AZA cell quota, which arguably are most relevant in directly affecting AZA accumulation rate by suspension feeding bivalves. Preliminary information on AZA cell quota just pointed out a general variability of roughly 5 to $40 \mathrm{fg} \mathrm{cell}^{-1}$ in batch culture (Salas et al., 2011; Tillmann et al., 2009), but cell quota has not yet been systematically related to environmental growth conditions.

Dinoflagellate growth and toxin content have repeatedly been shown to be affected by environmental factors such as salinity, temperature, and light (Flynn et al., 1996; Gedaria et al., 2007; Maclean et al., 2003; Parkhill and Cembella, 1999; Xu et al., 2010), and by the use of aeration (Hu et al., 2006b; Morton and Bomber, 1994). Moreover, nutritional factors, and especially nitrogen and phosphate ratio, also affect dinoflagellate growth and toxin cell quota 
(Flynn et al., 1996; Hu et al., 2006a; Hwang and Lu, 2000; Lartigue et al., 2009). However, chemical structures of algal biotoxins differ between toxic species of microalgae and thus factors influencing toxin cell quota might vary for different group and/or species (Graneli, 2006).

This work on $A$. spinosum aims at understanding the effect of environmental factors (temperature, salinity, light and aeration) as well as nutritional factors (culture medium, nitrate, urea, ammonium, phosphate, N/P ratios) on growth, cell yield and AZA cell quota in batch culture and/or photobioreactors run in continuous culture mode with the main aim to facilitate and enhance a sustainable production of AZAs from $A$. spinosum culture. These toxins are still necessary for instrument calibration in continuous monitoring programs and for toxicological studies. In addition, this study will improve our understanding on $A$. spinosum and will give initial informations on factors that might influence $A$. spinosum bloom formation and their toxicological effects.

\section{Material and methods}

\subsection{A. spinosum}

\subsubsection{Stock culture condition}

A. spinosum (strain 3D9) was maintained in $50 \mathrm{~mL}$ batch cultures (70 mL sterile polystyrene flask) at $18^{\circ} \mathrm{C}$, at a salinity of 35 , a photon flux density (PFD) of $200 \mu \mathrm{mol} \mathrm{m}^{-2} \mathrm{~s}^{-1}$ and a photoperiod of $16 \mathrm{~h}$ of light and $8 \mathrm{~h}$ of dark. Cultures were grown in $0.22 \mu \mathrm{m}$ filtered seawater, enriched with $\mathrm{K}$ medium (Keller et al., 1987), which was slightly modified (without addition of $\mathrm{NH}_{4} \mathrm{Cl}$, silicate and tris buffer, and with addition of $\mathrm{Na}_{2} \mathrm{SeO}_{3}\left(10^{-8} \mathrm{M}\right)$ ). The stock culture was maintained in the growth phase by transferring weekly into fresh medium.

\subsubsection{Experimental culture conditions}

For experimental purposes, batch and continuous culture were used:

Batch cultures were prepared in two different volumes, $70 \mathrm{~mL}$ sterile polystyrene flasks or $10 \mathrm{~L}$ flat bottomed glass flasks. Initial cell concentrations were between 5 to $20 \times 10^{3}$ cell $\mathrm{mL}^{-1}$ and the cultures were grown until stationary phase. Growth conditions were as described for the stock culture with the exception of the respective treatment condition.

Continuous cultures were maintained in 2.5 or $100 \mathrm{~L}$ chemostats. The photobioreactors were made of transparent polymethyl methacrylate and operated under the following conditions: the $\mathrm{pH}$ was regulated at 7.9 using $\mathrm{CO}_{2}$ addition, the temperature was kept constant at $18^{\circ} \mathrm{C}$, light was provided on one side of the reactor using neon tubes at identical PFD and photoperiod as the stock cultures, and a Rushton turbine was used to homogenize the culture medium. Prior inoculation, photobioreactors were sterilized using peroxyacetic acid at $5 \mathrm{ppm}$ for $30 \mathrm{~min}$ and rinsed twice using filtered sea water $(0.22 \mu \mathrm{m})$. The photobioreactors were inoculated with $A$. spinosum culture to reach an initial concentration of $70 \times 10^{3}$ cell $\mathrm{mL}^{-1}$ and a fixed dilution rate $\left(0.3\right.$ and 0.2 day $^{-1}$ in 2.5 or $100 \mathrm{~L}$ chemostats, respectively) was applied and maintained until steady state. 


\subsection{Environmental factors}

To independently assess the effect of temperature, salinity and PFD on $A$. spinosum growth and toxin production in batch culture, the cells were inoculated using an aliquot from the linear growth phase of a stock culture, and grown under the different conditions in triplicate $(50 \mathrm{~mL})$ until stationary phase.

Effect of temperature was assessed at $10,14,18,22,26^{\circ} \mathrm{C}$ with a PFD at $50 \mu \mathrm{mol} \mathrm{m}^{-2} \mathrm{~s}^{-1}$.

Effect of salinity was assessed at: $10,20,30,32,35$, and 40 . The salinity was adjusted by dilution with Milli- ${ }^{\circledR}$ water (Millipore) or evaporation, verified with a refractometer (Atago S/Mill) and nutrients were added subsequently.

Effect of the PFD was assessed at 50,100, 150, 200 and $250 \mu \mathrm{mol} \mathrm{m} \mathrm{m}^{-2} \mathrm{~s}^{-1}$ as quantified with a spherical quantum sensor (LI-250 light meter, LI-COR). In addition, the effect of the PFD on $A$. spinosum growth and toxin production in continuous culture was evaluated using two photobioreactors $\left(100 \mathrm{~L}\right.$, dilution rate: 0.2 day $\left.^{-1}\right)$. PFD was gradually increased: $1^{\text {st }}$ step 100 , $2^{\text {nd }}$ step 200 and $3^{\text {rd }}$ step $400 \mu \mathrm{mol} \mathrm{m}^{-2} \mathrm{~s}^{-1}$.

To evaluate the effect of aeration on growth, $A$. spinosum was cultured in triplicate $10 \mathrm{~L}$ flat bottomed glass flasks with and without aeration $\left(\sim 1 \mathrm{~L} \mathrm{~min}^{-1}\right.$ for a $10 \mathrm{~L}$ culture volume, air was $0.2 \mu \mathrm{m}$ prefiltered and administered using a glass tube, $\mathrm{NaH}_{2} \mathrm{PO}_{4} \mathrm{H}_{2} \mathrm{O}$ was the source of phosphate in this experiment).

\subsection{Nutritional factors}

\subsubsection{Culture medium}

Three different culture media were tested, The first was K-medium (Keller et al., 1987) in its modified version used to maintain the stock culture, the second medium was the same but now contained tris buffer, the third one was an $\mathrm{L} 1$ medium (using a $\mathrm{K}_{2} \mathrm{CrO}_{4}$ concentration in final medium equal to $110^{-8} \mathrm{M}$ ) (Guillard and Hargraves, 1993) and the last one an L1 medium with addition of $3 \mathrm{~mL}$ of soil extract (following the protocol SE1 of the Culture Collection of Algae and Protozoa (CCAP)). Before measuring growth, cell yield and toxin cell quota, cultures were pre-adapted to the experimental media for several weeks.

Next, potential effects of using $\mathrm{K}$ modified medium of different strength were assessed in photobioreactors $\left(100 \mathrm{~L}\right.$, dilution rate: 0.2 day $\left.^{-1}\right)$ using the following medium concentration: $0.5 \mathrm{Kmod}, \mathrm{Kmod}$ and $2 \mathrm{Kmod}$.

\subsubsection{Nitrogen and phosphate sources}

An experiment was carried out in duplicate to assess the effect of the addition of ammonium and/or urea to a culture medium already containing nitrate (initial concentration of nitrate: 50 $\mu \mathrm{M}$, initial concentration of ammonium: 0 or $100 \mu \mathrm{M}$ and initial concentration of urea: 0 or $100 \mu \mathrm{M})$ ) on $A$. spinosum growth, cell concentration and toxin cell quota in $50 \mathrm{~mL}$ batch culture. Concerning the other nutrients, trace metals and vitamins were at the same concentration as used in the $\mathrm{K}$ medium (Keller et al., 1987)

Subsequently, nitrate $(882 \mu \mathrm{M})$ or urea $(100 \mu \mathrm{M})$ as sole nitrogen source on $A$. spinosum production and toxin cell quota were compared using two photobioreactors $(2.5 \mathrm{~L}$, dilution rate: 0.3 day $\left.^{-1}\right)$. 
In one experiment, addition of organic $\left(\mathrm{Na}_{2} \beta\right.$-glycerophosphate) or inorganic $\left(\mathrm{NaH}_{2} \mathrm{PO}_{4} \mathrm{H}_{2} \mathrm{O}\right)$ phosphate was compared, to evaluate their respective effect on $A$. spinosum grown in batch cultures $(50 \mathrm{~mL})$.

Three N/P ratios $\left(\mathrm{NO}_{3}{ }^{-} / \mathrm{PO}_{4}{ }^{3-}\right.$ in $\left.\mu \mathrm{M}: 40 / 5,160 / 10,882 / 10\right)$ were tested using the $2.5 \mathrm{~L}$ chemostat at a dilution rate of 0.3 day $^{-1}$.

\subsection{Cell growth}

Cell concentrations (cell $\mathrm{mL}^{-1}$ ), mean estimated spherical diameter (ESD, $\mu \mathrm{m}$ ) and total biovolume $\left(\mu \mathrm{m}^{3} \mathrm{~mL}^{-1}\right.$, spherical equivalent) were assessed daily using a particle counter (Multisizer 3 Coulter counter, Beckman).

In batch culture: growth rates $\left(\mu\right.$ in day $^{-1}$ ) were calculated following the equation (Guillard, 1973):

$$
\mu=\left(\ln X_{t}-\ln X_{0}\right) / t
$$

Where $X_{0}$ is the initial cell density and $X_{t}$ is the cell density after $t$ days (the day chosen for $t$ are represented by a star $\left(^{*}\right)$ in the different graphics).

One experiment (i.e. section 2.2. aeration) yielded a sufficient number of points to apply a Gompertz model to assess maximum growth rate $\left(\mu_{\max }\right.$ in $\left.\mathrm{d}^{-1}\right)$, maximun cell concentration ( $\alpha$ $=\ln (X / X 0)$ with $X$ in cell $\left.\mathrm{mL}^{-1}\right)$ and latency time ( $\lambda$ in day, if present) with a MatLab software:

$$
f(t)=\alpha \times \exp \left(-\exp \left(\mu_{\max } \times \exp (1) / \alpha \times(\lambda-t)+1\right)\right)
$$

In continuous culture, the bioreactors were considered to have reached steady state after a minimum of 3 days at the same microalgal concentration $( \pm 10 \%)$.

\subsection{AZA analysis}

\subsubsection{Reagents}

Acetone and methanol (MeOH) were obtained as HPLC grade solvents from JT Baker. Water for analysis was supplied by a Milli-Q integral 3 system (Millipore). Formic acid (Puriss quality) and ammonium formate (Purity for MS) were from Sigma Aldrich. AZA1-2 calibrants for LC-MS/MS analysis were dilutions of certified AZA1 solutions obtained from the National Research Council Canada.

\subsubsection{A. spinosum}

The analytical procedure had previously been optimized (Jauffrais et al., 2012a). Briefly, $A$. spinosum cells were collected by centrifugation $\left(10 \mathrm{ml}, 2500 \mathrm{~g}, 20 \mathrm{~min}, 4^{\circ} \mathrm{C}\right)$. The supernatant was collected (see below) and the pellet re-suspended using $0.5 \mathrm{~mL}$ of acetone, transferred to an Eppendorf tube $(1.5 \mathrm{~mL})$ and bath sonicated $(10 \mathrm{~min})$. After sonication, the aliquot was centrifuged $\left(15000 \mathrm{~g}, 10 \mathrm{~min}, 4^{\circ} \mathrm{C}\right)$. The supernatant was transferred into a $5 \mathrm{~mL}$ glass tube and the pellet was re-suspended in $0.5 \mathrm{~mL}$ of acetone, homogenized and centrifuged again. The supernatants were transferred again into the same $5 \mathrm{~mL}$ glass tube and gently evaporated under nitrogen on a heating block at $35^{\circ} \mathrm{C}$. This process was repeated three times in total. After evaporation of supernatants, the residue was reconstituted in $1 \mathrm{~mL}$ methanol, filtered with NANOSEP MF centrifugal filter $0.2 \mu \mathrm{m}$ (PALL) $\left(6000 \mathrm{~g}, 3 \mathrm{~min}, 4^{\circ} \mathrm{C}\right)$, and transferred into a HPLC vial for analysis. 


\subsubsection{Supernatant}

Solid Phase extraction (SPE) was carried out on Oasis HLB cartridges (Waters) to estimate AZA concentration in the $10 \mathrm{~mL}$ supernatant. Oasis HLB cartridges (6 cc, $200 \mathrm{mg}$ ) were activated with methanol $(10 \mathrm{~mL})$ and washed with a solution of water-methanol $(9: 1 \mathrm{v} / \mathrm{v}$, $10 \mathrm{~mL}$ ). The sample was loaded dropwise (gravity), once loaded the cartridge was washed with the solution of water-methanol $(9: 1 \mathrm{v} / \mathrm{v}, 10 \mathrm{~mL})$ and eluted with $3 \mathrm{~mL}$ of methanol in a glass tube. After evaporation of the methanol, the residue was reconstituted in $0.5 \mathrm{~mL}$ methanol, filtered with NANOSEP MF centrifugal filter $0.2 \mu \mathrm{m}$ (PALL) $\left(6000 \mathrm{~g}, 3 \mathrm{~min}, 4^{\circ} \mathrm{C}\right)$, and transferred into a HPLC vial for analysis.

\subsubsection{LC-MS/MS analysis}

The samples were analyzed by LC-MS/MS using an Agilent 1100 model coupled to a triple quadrupole mass spectrometer (API 2000, SCIEX-Applied Biosystems) for quantification of AZAs. Chromatography was performed using a Hypersil BDS C8 column $(50 \times 2 \mathrm{~mm}, 3 \mu \mathrm{m}$, Thermo scientific) and an isocratic elution at $250 \mu \mathrm{L} \cdot \mathrm{min}^{-1}$ at $20^{\circ} \mathrm{C}$ for $10 \mathrm{~min}$. Mobile phase $\mathrm{A}$ was $100 \%$ water $(25 \%)$ and mobile phase B $(75 \%)$ consisted of acetonitrile-water (95:5) both containing $2 \mathrm{mM}$ ammonium formate and $50 \mathrm{mM}$ formic acid. The injection volume was $5 \mu \mathrm{L}$ and the column and sample temperatures were 20 and $5^{\circ} \mathrm{C}$, respectively.

The declustering potential was $140 \mathrm{~V}$, the entrance potential $10 \mathrm{~V}$, the cell exit potential $35 \mathrm{~V}$, and the collision cell were 50 and $70 \mathrm{~V}$ for fragmentation 1 and 2 respectively. The electrospray ionisation interface (ESI) was operated using the following parameters: curtain gas: $19 \mathrm{psi}$; temperature: $350^{\circ} \mathrm{C}$; gas 1 : 30 psi; gas 2: 50 psi; CAD gas: 5 psi; ion spray voltage: $5800 \mathrm{~V}$.

Azaspiracids were quantified against NRC certified AZA1 standards. The two most intense product ions were selected with the following transitions: AZA1 $\mathrm{m} / z \quad 842.5 \rightarrow 824.5$ and $842.5 \rightarrow 672.4$, and AZA2 $\mathrm{m} / \mathrm{z} 856.5 \rightarrow 838.5$ and $856.5 \rightarrow 672.4$.

\subsection{Nutrient analysis in culture medium}

For the analysis of dissolved nitrate and inorganic phosphate, the culture medium was filtered through a $0.22 \mu \mathrm{m}$ syringe filtered (FP30/0.2 Whatman) in $50 \mathrm{~mL}$ pretreated plastic tubes (Sarstedt, pre-washed with $1 \mathrm{M} \mathrm{HCl}$ and then rinsed three times with Milli-Q water) and stored at $-20^{\circ} \mathrm{C}$ until analysis (Aminot and Kerouel, 2007).

\subsection{Statistical analysis}

Data are expressed as mean \pm standard deviation (SD). Depending on the data, statistical analyses consisted either in one-way analysis of variance (ANOVA), or in a Kruskal-Wallis test, followed, when necessary, by a Fisher's least significant difference procedure or a boxand-whisker plot. Differences were considered significant at $p<0.05$. Before each ANOVA analysis or Kruskal-Wallis test, normality and equality of variance were tested to decide which test was going to be used.

Statistical analyses were carried out using Statgraphics Centurion XV.I (StatPoint Technologies, Inc.). 


\section{Results}

\subsection{Environmental factors}

\subsubsection{Temperature}

The largest differences of $A$. spinosum growth of this study were observed when using different temperatures (Fig. 1a and Table 1). A. spinosum was able to grow in the whole range of temperatures tested $\left(10\right.$ to $\left.26^{\circ} \mathrm{C}\right)$ and always reached cell concentration above $50 \times 10^{3}$ cell $\mathrm{mL}^{-1}$, but growth clearly was temperature dependent. The best growth was found at $22^{\circ} \mathrm{C}\left(0.46 \mathrm{~d}^{-1}\right)$, whereas growth was much slower $\left(0.12 \mathrm{~d}^{-1}\right)$ at $10^{\circ} \mathrm{C}$.

AZA cell quota were found to be antagonist to growth, as at slow growth a high AZA cell quota was found $\left(10^{\circ} \mathrm{C}, 220 \mathrm{fg} \mathrm{cell}^{-1}\right)$ whereas fast growing algae at higher temperatures had a lower AZA cell quotas (e.g. $22^{\circ} \mathrm{C}, 8 \mathrm{fg} \mathrm{cell}^{-1}$ ).

\subsubsection{Salinity}

A. spinosum inoculated at a salinity of 10 were not measurable with the particle counter on the following day, and cells inoculated at a salinity of 20 were only measurable until the second day of the experiment but no further; however, growth of $A$. spinosum was observed between 30 and 40 of salinity (Fig. $1 \mathrm{~b}$ and Table 1), with growth rates assessed between 0.22 and $0.34 \mathrm{~d}^{-1}$. Fastest growth and highest final cell yield was obtained at a salinity of 35 whereas the highest toxin cell quota was obtained at the two extreme salinities, 30 and 40 .

\subsubsection{Photon flux density}

When grown at different PFDs ranging from 50 to $250 \mu \mathrm{mol} \mathrm{m} \mathrm{m}^{-2} \mathrm{~s}^{-1}$, growth of $A$. spinosum was comparable for irradiance down to $100 \mu \mathrm{mol} \mathrm{m} \mathrm{m}^{-2} \mathrm{~s}^{-1}$ and slightly but significantly reduced at $50 \mu \mathrm{mol} \mathrm{m} \mathrm{m}^{-2} \mathrm{~s}^{-1}$. Concerning AZA cell quota and the maximum cell concentration, no differences were found between the different PFD tested (Fig. 1c and Table 1).

In addition, $A$. spinosum was grown in continuous culture at different light conditions (Fig. 3). In stirred photobioreactors, a slightly higher steady state cell concentration was observed at 200 and $400 \mu \mathrm{mol} \mathrm{m}^{-2} \mathrm{~s}^{-1}$ compared to growth at $100 \mu \mathrm{mol} \mathrm{m} \mathrm{m}^{-2} \mathrm{~s}^{-1}$. However, the main effect found was on the AZA cell quota, where an increase by a factor of 3 was observed between the lowest PFD and the highest one (Table 2). At the same time an increase in ESD was observed as PFD increased.

\subsubsection{Aeration}

In $10 \mathrm{~L}$ batch culture flasks with aeration, $A$. spinosum had a growth rate of $0.41 \mathrm{~d}^{-1}$, reached maximum cell concentration of $315 \times 10^{3}$ cell mL ${ }^{-1}$ and aeration prolonged the length of the stationary phase (Table 1 and Fig 1d). Without aeration, growth was $0.66 \mathrm{~d}^{-1}$ and the final cell yield was $90 \times 10^{3}$ cell $\mathrm{mL}^{-1}$ (Table 1 and and Fig 1d). Maximum AZA cell quota was substantially higher with aeration than without aeration, i.e. $122 \pm 2$ and $15 \pm 2 \mathrm{fg} \mathrm{cell}^{-1}$ ) but cell quota were similar when compared for the same sampling day (Fig1d, Fig 2d, Table 1).

The data set of the batch culture in $10 \mathrm{~L}$ aerated flasks was also used to apply a Gompertzmodel to assess $A$. spinosum maximum growth rate, maximum cell concentration, and 
latency time, and to follow the variation of the mean ESD, the AZA cell quota and the nitrate and phosphate consumption during a batch culture (Fig. 2).

The ESD decreased during the first days of the culture until growth rate begun to decrease (day 4 ) and then increased until the end of the stationary phase and finally decreased as senescence phase begun (Fig. 2a). The maximum growth rate found by the model under this condition was equal to 0.57 day $^{-1}$, with a maximum cell concentration of $302 \times 10^{3}$ cell mL $^{-1}$, and a negligible latency time (Fig. $2 \mathrm{~b}$ ). Using the $\mathrm{K}$ modified medium, phosphate with concentration close to $0 \mu \mathrm{M}$ was found to be depleted after 14 days of culture (Fig. 2c). Interestingly, AZA cell quota increased from the beginning of the culture to the end of the stationary phase where it drastically decreased. This final drop of intracellular toxin was linked to an increase of extracellular toxin dissolved in the culture medium. Effectively, until day 14 the percentage of dissolved AZAs was below $1 \%$ of total AZAs, whereas for the last day of the experiment this percentage increased up to $35 \%$ (data not shown). However, we also noticed that the total amount of AZAs (intra + extracellular) decreased from day 14 to 17 $(-31 \%)$, indicating possible transformation/degradation of AZA1 and -2 in seawater. The intracellular AZA2/AZA1 ratio was almost identical during the whole growth curve $(0.30 \pm 0.02)$.

\subsection{Nutritional factors}

\subsubsection{Medium}

A. spinosum grew with all four different growth media tested with growth rates ranging between 0.39 and 0.45 day $^{-1}$ (Fig. 4, Table 2). Even though growth rates were similar to each other, statistical differences $(P=0.02)$ were found, and the $K$ modified medium (Kmod) yielded the highest growth rate. No statistically significant differences were found concerning the $A$. spinosum maximum concentration. Some small but statistically significant differences were noticed in AZA cell quota $(\mathrm{Kmod} 2>\mathrm{Kmod}=\mathrm{L} 1=\mathrm{L} 1+\mathrm{SE})$.

Kmod was tested at different concentrations in continuous culture. Cell concentration at steady state was positively related to the medium concentration (Table 2), and AZA cell quota were negatively correlated to it. Differences were also found in ESD as at a lower medium concentration the ESD was larger than at high medium concentration.

\subsubsection{Nitrogen and phosphate sources}

When simultaneously providing different nitrogen sources (nitrate or nitrate with ammonium and/or urea), A. spinosum showed a reduction of growth with the addition of ammonium (Fig. 5 ), whereas addition of urea had no effect on growth. For all combinations, comparable maximum cell concentrations $\left(10010^{3}\right.$ cells ml-1) and AZA cell quota (10-20 $\left.\mathrm{fg} \mathrm{cell}^{-1}\right)$ were observed (Table 4).

The production of $A$. spinosum on culture media containing nitrate or urea was also studied in photobioreactors (Table 2), and results found between the two conditions were close; still, a slight difference was found in favor of nitrate in cell concentration as well as in mean ESD and cellular volume, but no differences were found in AZA cell quota (41 vs $42 \mathrm{fg} \mathrm{cell}^{-1}$ ).

Two sources of phosphate were also tested in batch culture and results were found to be similar in terms of growth, maximum cell concentration and AZA cell quota using either $\mathrm{NaH}_{2} \mathrm{PO}_{4}$ or $\beta$-glycerophosphate (Table 3). 
A. spinosum grown in photobioreactors at different $\mathrm{NO}_{3} / \mathrm{PO}_{4}$ ratios showed that steady state cell concentration increased with the absolute amount of nitrate. Likewise, AZA cell quota was maximized at the highest N/P ratio tested (Table 2).

\section{Discussion}

There is a general need for purified AZA toxins for either LC-MS/MS calibration in the frame of monitoring programs and for extended and detailed toxicological studies, and the availability of $A$. spinosum opened the possibility to use cultures as a sustained source of toxins. Understanding of environmental and nutritional factors affecting $A$. spinosum growth and toxin production/accumulation constitutes a pre-requisite to allow and improve largescale high biomass culturing and AZA production and thus was the main motivation for this study. It is important to note that the experiments were therefore started at relatively high cell densities for dinoflagellate culture. Batch cultures thus only initially (if ever) showed exponential growth with a density independent maximum rate but were generally characterized by a more linear increase in density typical for the transition from the initial maximum exponential increase to growth cessation at the stationary phase. Nevertheless, growth of different treatments, albeit not representing the maximum growth rate of that particular environmental condition, allowed a direct comparison and yielded some first insights into the ecological characteristics of $A$. spinosum. We found AZA-toxins with an unchanged toxin profile in significant amounts for all environmental conditions tested, indicating that toxin production of $A$. spinosum is constitutive. Nevertheless, quantitative differences in the toxin cell quota were found to vary more than 20 fold. Generally, when comparing growth and AZA cell quota at different environmental conditions, lower growth were consistently coupled with higher toxin cells quotas underlining the notion that toxin production is not strictly coupled to growth. The extended data set of aerated $10 \mathrm{~L}$ batch cultures allow for a detailed analysis of the dynamics of toxin cell quota during growth. As it has been determined for PSP producers (Boyer et al., 1987; Guillard, 1975; Kim et al., 1993), AZA toxin quota of $A$. spinosum significantly increased with decreasing growth rate during the transition from the initial maximum exponential increase to growth cessation and peaked in the late stationary phase, which is comparable to other dinoflagellate producers of polyether toxins (Bomber and Tindall, 1988; Guerrini et al., 2010; Pan et al., 1999). Such a higher toxin cell quota in stationary phase has often been related to phosphate depletion (McLachlan et al., 1994; Morlaix and Lassus, 1992; Vanucci et al., 2010). Given the high surplus of nitrate in K-medium and the very low phosphate concentrations at stationary phase (see Fig. 2c), P-limitation also was likely the cause of growth cessation in the aerated high biomass batch cultures. Likewise, phosphorous is assumed to be the growth limiting factors in chemostat-mode bioreactors (see below). In any case, the high dynamic variability of toxin cell quota over the growth phases shown above, hinder a direct and straightforward comparison of toxin cell quota of different treatments when cultures were just once sampled at slightly different growth phases. Nevertheless, as cultures for cell quota determination were always sampled at early stationary phase, an interpretation of the major differences in cell quota as a response to the respective environmental factor is certainly possible.

\subsection{Environmental factors}

A. spinosum was found to grow in a wide range of temperatures. The highest growth rate was observed at $22^{\circ} \mathrm{C}$, and a drop of the temperature corresponded to a decrease in growth that concurred with a very pronounced increase in toxin content. This observation was also mentioned in the literature with other toxic dinoflagellates (Anderson et al., 1990; Guerrini et al., 2007; Navarro et al., 2006; Ogata et al., 1987). A temperature above the optimum growth temperaure (e.g. $26^{\circ} \mathrm{C}$ in the present case) can also lead to an increase in toxin quota in 
some species (Protoceratium reticulatum (Guerrini et al., 2007), Prorocentrum hoffmannianum (Morton et al., 1994) and $A$. spinosum in the present study). With a more than 20 fold difference, low temperature caused the by far largest AZA cell quota of $A$. spinosum. As for any increase in cell quota, this observation can be due to either an increase in toxin production rate as a response to an (environmental) stress and/or due to a general decrease in growth rate causing toxin accumulation even with unchanged toxin production. To follow this up calculations were made to relate AZA cell quota to the time necessary for cell division and thus to the amount of light received and to cell volume (table 5). The lower growth and thus the time the cells were illuminated before cell division as well as the larger cell volume of low temperature grown cells may partly explain the differences in AZA cell quota; however, a factor of five is still unexplained when normalizing to both the amount of light received and the cell volume obtained. Thus, lower temperature appears to also increase the absolute rate of biosynthesis of azaspiracids. This large effect of low temperature elevating cell quota to more than $200 \mathrm{fg} \mathrm{cell}^{-1}$ in the stationary phase when grown at $10^{\circ} \mathrm{C}$ may help to explain the rather unexpected but repeated AZA problems in Irish mussels during winter month. In terms of mass culturing for toxin harvesting, application of a low growth temperature seems promising to maximize total toxin yield, even when considering the long time needed to reach high biomass and the lower final cell yield found in batch culture. On the other hand, however, it will also impose a technical challenge to cool large scale photobioreactors so the practical implementation for routine large scale culturing is quite unlikely.

A. spinosum cells acclimatized to a salinity of 35 were able to grow well in a range of proximate salinities (30 to 40), and were able to survive for a few days at a salinity of 20 . Yet better survival could possibly be obtained with a progressive acclimation of the organism to different salinities. Even though this range does not classify $A$. spinosum as a euryhaline species (at a salinity of 10 no survival was observed), the tolerance for short and sudden periods to decreased salinity may at least partially explain why $A$. spinosum fares relatively well in Irish bays or Norwegian fjords, where rainfall may temporarily contribute to large freshwater inputs (and hence drop in salinity). While cells grown at a salinity of 30 and 40 were found to contain slightly more toxins (Table 1), this difference may be confounded by the fact that toxin analysis was carried out on the same day for all cultures, yet some cultures were at that stage in senescence phase whereas others were still in stationary phase (see also figure 2 for decreased toxin content at the beginning of the senescence phase). Furthermore, the significant difference in AZA cell quota found at a salinity of 40 can be partially explained by a slightly larger mean ESD and thus a larger cellular volume found at a salinity of 40 than at 35 (Table 1).

Growth response of $A$. spinosum at different light levels gave no signs of photoinhibition of growth at higher light levels (tested up to $250 \mu \mathrm{mol} \mathrm{m} \mathrm{m}^{-1}$ ). Growth was almost saturated down to the lowest light level tested $\left(50 \mu \mathrm{mol} \mathrm{m} \mathrm{m}^{-2} \mathrm{~s}^{-1}\right)$, where only a slight decrease in growth was noticed. However, the characteristics of a growth-vs-light-curve at low light (e.g. to determine the light compensation point or the light leading to half $\mu_{\max }$ ) has yet to be determined so a general classification of $A$. spinosum as a "low light" or "high light" adapted species is currently not possible. It is often assumed that photosynthesis in dinoflagellates plays an important role in the synthesis of toxins (Ogata et al., 1987). However, for $A$. spinosum different PFD in batch culture was apparently not affecting AZA cell quota, suggesting that when growth is light saturated, excess energy at higher light is not used to increase AZA production. In contrast, when grown in chemostat at potentially nutrient limited conditions (low dilution rate), different PDFs clearly affected AZA cell quota. An increase by a factor of 3 was observed between the lowest photon flux density and the highest one, indicating that under nutrient limiting growth, surplus light energy lead to an increased AZA accumulation, a fact that can be used to further improve AZA mass production (Jauffrais et al., 2012b). 
Addition of turbulences by either aeration, agitation or shaking of a dinoflagellate culture is known to either increase cell concentration and toxin production (Morton and Bomber, 1994) or to inhibit growth (Berdalet, 1992; Pollingher and Zemel, 1981). In the case of Alexandrium minutum, turbulence caused a decrease in growth rate, biomass, and lower concentration of paralytic shellfish toxins and production of ecdysed cysts (Bolli et al., 2007). However, all authors do not agree with these effects of turbulence and some believe that some of these experiments on turbulence were conducted above a growth inhibition threshold (Burkholder et al., 2006). Indeed, turbulence seemed to be dependent upon the species and the applied intensity. Using turbulence intensities comparable to natural conditions, a wide range of bloom forming dinoflagellate species, their growth rate and cell concentration were either affected (positively or negatively) or unaffected (Sullivan and Swift, 2003). A. spinosum growth was only slightly affected by a significant, albeit unquantified, level of turbulence as introduced here by aeration, which was somewhat unexpected given the cursory notion of $A$. spinosum as a small and fragile thin thecate dinoflagellate. However, turbulence resistance is an important prerequisite for mass culturing in photobioreactors, where stirring and aeration $\left(\mathrm{CO}_{2}\right.$ addition) are used to regulate $\mathrm{pH}$ and to keep cells in suspension. In batch culture, aeration drastically increased final cell yield (biomass) and prolonged the length of the stationary phase. We could not detect a direct short-term effect of turbulence on AZA cell quota as values measured on day 4 were similar ( $16 \mathrm{fg}$ cell unaerated vs $20 \mathrm{fg}$ cell aerated). The enormous increase of late stationary phase AZA cell quota and final biomass in aerated cultures compared to non-aerated batches might be due to lowering or preventing carbon limitation (enhanced gas exchange) or by avoiding direct negative effects of high $\mathrm{pH}$ potentially prevailing in non-aerated cultures (Hansen et al., 2007; Rost et al., 2006) or to nutrient depletion due to the prolonged growth and stationary phase.

\subsection{Nutritional factors}

Although the nutritional requirements of $A$. spinosum in terms of trace elements/vitamins etc. have not yet been defined precisely, culture work performed so far showed that the species is easy to grow on a number of different standard culture media. These include K-medium of various strength (but with omission of ammonium, (Tillmann et al., 2009) and this study)), F/2 medium (Salas et al., 2011) , or L1 medium with or without addition of soil extract (this study). The omission of tris buffer (Kmod), as tested here for technical reasons (in photobioreactors the $\mathrm{pH}$ is already controlled by addition of $\mathrm{CO}_{2}$ ) was no problem and even slightly enhanced growth for unknown reasons, however, $\mathrm{pH}$ was not continuously analysed in these cultures and direct effects of $\mathrm{pH}$ on $A$. spinosum still need to be addressed. In conclusion, the use of different media, including the addition of soil extract, did not largely affect growth and toxin cell quota and did not indicate any unusual nutrient requirement. In terms of major nutrient, $A$. spinosum was able to grow and to produce toxins with different sources of nitrogen (nitrate, urea and ammonium) and phosphate $\left(\mathrm{NaH}_{2} \mathrm{PO}_{4}\right.$ and $\mathrm{Na}$ Bglycerophosphate). The potential to use urea is important as during the last four decades the amount of urea in fertilizers has increased drastically in many agricultural regions of the world and has been linked to increasing paralytic shellfish poisoning events (Glibert et al., 2006). Addition of ammonium, however, a nutrient known to be rapidly toxic to some dinoflagellates (Chang and McClean, 1997; Leong and Taguchi, 2004), reduced growth and thus conformed the empirical notion that omitting ammonium from the standard K-recipe improved growth for $A$. spinosum (Tillmann et al., 2009).

Without doubt, growth and toxin production of dinoflagellates are influenced by the supply with nitrogen and phosphate (Anderson et al., 1990; Flynn et al., 1994; John and Flynn, 2000). Increasing the amount of nutrient in the inflowing medium in chemostat bioreactors increased the steady state cell concentration (e.g. a 1.8 fold increase when using double strength K-medium compared to normal K) but also caused an almost two-fold decreased 
AZA cell quota (see Table 2). Thus, beside nutrient limitation, another factor related to the higher steady state biomass must have simultaneously affected the AZA cell quota. Although negative effects of autoinhibitory compounds cannot be ruled out, self shading is probably the most important aspect here as decreasing light intensity at nutrient limited chemostat growth clearly decreased toxin cell quota (Table 2). Such a synergistic combinations of effects (phosphate limited growth at high light intensities) may further improve the large-scale culturing approach developed by Jauffrais et al. (2012b), where an increase in PFD applied during the "maturation" period might further enhance AZA production once high cell concentrations are reached.

Anthropogenic addition of nitrogen or phosphate into the coastal water unbalanced the Redfield N/P ratio (16/1), commonly found in the ocean, and might modify growth and toxin production of toxic dinoflagellates (Glibert et al., 2006; Heisler et al., 2008). In polyether toxin producers, $\mathrm{P}$ limiting conditions seem to enhance toxin quota as already mentioned and $\mathrm{N}$ limiting conditions may also maximize toxin quota in some organisms (Vannucci et al., 2010), but in both cases, $\mathrm{N}$ or $\mathrm{P}$ limitation reduced growth and even toxin quota for Ostreopsis cf. ovata (Vanucci et al., 2012). Our preliminary experiments using three different N/P ratios in chemostat continuous cultures with higher AZA cell quota at the highest N/P ratio (Table 3 ) indicate that phosphorous limitation might play a role in promoting high toxin cell quotas, but it still need to be determined if this is caused by accumulation (reduced growth) or/and by an increase in toxin production rate. In the future, low biomass continuous culture experiment using different dilution rates (different degrees of nutrient limitations) are needed to more thoroughly clarify the effects of nutrient limitation on $A$. spinosum toxin production/accumulation.

\section{Conclusions}

A. spinosum was found to grow with all media tested and in a wide range of conditions, from 10 to $26^{\circ} \mathrm{C}, 30$ to $40 \mathrm{psu}, 50$ to $400 \mu \mathrm{mol} \mathrm{m} \mathrm{s}^{-1}$ and with or without aeration; with best growth and/or highest final cell yield found at $35 \mathrm{psu}$, from 18 to $22^{\circ} \mathrm{C}$ and with aeration. AZA-toxins with an unchanged toxin profile were found in significant amounts for all environmental conditions tested and thus indicate that toxin production of $A$. spinosum is constitutive. Nevertheless, quantitative differences in the toxin cell quota may be large. AZA cell quota were most significantly affected by low temperature: the AZA cell quota was more than 20 times higher at $10^{\circ} \mathrm{C}\left(220 \mathrm{fg} \mathrm{cell}^{-1}\right)$ than at temperatures comprised between 18 and $26^{\circ} \mathrm{C}$. Likewise, but to a lesser degree, AZA cell quota were enhanced in aerated stationary phase cultures and at high irradiance when cells were grown in chemostats. Decreasing the nutrient concentration in the ingoing medium $(0.5 \mathrm{Kmod})$ in chemostats improved AZA cell quota while higher concentration ( $2 \mathrm{Kmod}$ ) improved maximal cell concentration.

These experiments on the effects of environmental and nutritional factors on $A$. spinosum improved our knowledge on its culture and allowed its growth in pilot scale photobioreactors for AZA1 and -2 production (Jauffrais et al., 2012b). Furthermore, the now well defined ability of this species to support conditions applied in continuous cultures will enable more detailed future studies on the effect of nutrient limitations on growth, AZA toxin production and $A$. spinosum biochemical composition. Finally, the large differences in toxin cell quota observed under different environmental and nutritional conditions open possible routes of comparative gene expression studies for the elucidation of the genes involved in toxinogenesis. 


\section{Acknowledgement}

This project, ASTOX2 (Grant-Aid Agreement No. PBA/AF/08/001), is carried out under the Sea Change strategy with the support of the Marine Institute and the Marine Research Subprogramme of the National Development Plan 2007-2013, co-financed under the European Regional Development Fund. Further funding was obtained through Ifremer from the French Ministry of Education, Research and Technology through Programme 187 of the National Finance Law.

The authors would also like to thank all the members of the laboratory EMP/PHYC at the Atlantic Centre of Ifremer for their help and technical advice during this study as well as Yoann Le Merrer and Isabelle Truquet from the LER MPL at the Atlantic Centre of Ifremer for the nutrient analysis in culture media.

\section{References}

Akselman, R., Negri, R.M., 2012. Blooms of Azadinium cf. spinosum Elbrächter et Tillmann (Dinophyceae) in northern shelf waters of Argentina, southwestern Atlantic. Harmful Algae 19, 30-38.

Aminot, A., Kerouel, R., 2007. Dosage automatique des nutriments dans les eaux marines : méthode en flux continu, In: Ifremer (Ed.), Méthodes d'analyses en milieu marin.

Amzil, Z., Sibat, M., Royer, F., Savar, V., 2008. First report on azaspiracid and yessotoxin groups detection in French shellfish. Toxicon 52(1), 39-48.

Anderson, D.M., Kulis, D.M., Sullivan, J.J., Hall, S., Lee, C., 1990. Dynamics and physiology of saxitoxin production by the dinoflagellates Alexandrium spp Mar. Biol. 104(3), 511-524.

Berdalet, E., 1992. Effects of turbulence on the marine dinoflagellate Gymnodinium nelsonii. J. Phycol. 28(3), 267-272.

Bolli, L., Llaveria, G., Garces, E., Guadayol, O., van Lenning, K., Peters, F., Berdalet, E., 2007. Modulation of ecdysal cyst and toxin dynamics of two Alexandrium (Dinophyceae) species under small-scale turbulence. Biogeosci. 4(4), 559-567.

Bomber, J.W., Tindall, D.R., 1988. Genetic variability in toxin potencies among seventeen clones of Gambierdiscus toxicus (Dinophyceae). FASEB J. 2(4), A375-A375.

Boyer, G.L., Sullivan, J.J., Andersen, R.J., Harrison, P.J., Taylor, F.J.R., 1987. Effects of nutrient limitation on toxin production and composition in marine dinoflagellate Protogonyaulax tamarensis. Mar. Biol. 96(1), 123-128.

CCAP, SE1 (Soil Extract 1 - Marine cultures), http://www.ccap.ac.uk/media/pdfrecipes.htm, last access 2012/03/04.

Chang, F.H., McClean, M., 1997. Growth responses of Alexandrium minutum (Dinophyceae) as a function of three different nitrogen sources and irradiance. N. Z. J. Mar. Freshwater Res. 31(1), 1-7.

Flynn, K., Franco, J.M., Fernandez, P., Reguera, B., Zapata, M., Wood, G., Flynn, K.J., 1994. Changes in toxin content, biomass and pigments of the dinoflagellate Alexandrium 
minutum during nitrogen refeeding and growth into nitrogen and phosphorus stress. Mar. Ecol. Prog. Ser. 111(1-2), 99-109.

Flynn, K.J., Flynn, K., John, E.H., Reguera, B., Reyero, M.I., Franco, J.M., 1996. Changes in toxins, intracellular and dissolved free amino acids of the toxic dinoflagellate Gymnodinium catenatum in response to changes in inorganic nutrients and salinity. J. Plankton Res. 18(11), 2093-2111.

Furey, A., O'Doherty, S., O'Callaghan, K., Lehane, M., James, K.J., 2010. Azaspiracid poisoning (AZP) toxins in shellfish: toxicological and health considerations. Toxicon 56(2), 173-190.

Gedaria, A.I., Luckas, B., Reinhardt, K., Azanza, R.V., 2007. Growth response and toxin concentration of cultured Pyrodinium bahamense var. compressum to varying salinity and temperature conditions. Toxicon 50(4), 518-529.

Glibert, P., Harrison, J., Heil, C., Seitzinger, S., 2006. Escalating worldwide use of urea - A global change contributing to coastal eutrophication. Biogeochemistry 77(3), 441-463.

Gu, H., Luo, Z., Krock, B., Witt, M., Tillmann, U., 2013. Morphology, phylogeny and azaspiracid profile of Azadinium poporum (Dinophyceae) from the China Sea. Harmful Algae 21-22(0), 64-75.

Guerrini, F., Ciminiello, P., Dell'Aversano, C., Tartaglione, L., FattorusSo, E., Boni, L., Pistocchi, R., 2007. Influence of temperature, salinity and nutrient limitation on yessotoxin production and release by the dinoflagellate Protoceratium reticulatum in batch-cultures. Harmful Algae 6, 707-717.

Guerrini, F., Pezzolesi, L., Feller, A., Riccardi, M., Ciminiello, P., Dell'Aversano, C., Tartaglione, L., Dello lacovo, E., Fattorusso, E., Forino, M., Pistocchi, R., 2010. Comparative growth and toxin profile of cultured Ostreopsis ovata from the Tyrrhenian and Adriatic Seas. Toxicon 55(2-3), 211-220.

Guillard, R.R.L., 1973. Division rates, In: Stein, J.R. (Ed.), Handbook of phycological methods. Cambridge University Press, Cambridge, pp. 289-312.

Guillard, R.R.L., 1975. Culture of phytoplankton for feeding marine invertebrates, In: Smith, W.L., Chanley, M.H. (Eds.), Culture of Marine Invertebrate Animals. Plenum Press, New York, USA, pp. 26-60.

Guillard, R.R.L., Hargraves, P.E., 1993. Stichochrysis immobolis is a diatom, not a chrysophyte. Phycologia 32(3), 234-236.

Hansen, P.J., Lundholm, N., Rost, B., 2007. Growth limitation in marine red-tide dinoflagellates: effects of $\mathrm{pH}$ versus inorganic carbon availability. Marine Ecology Progress Series 334, 63-71.

Heisler, J., Glibert, P.M., Burkholder, J.M., Anderson, D.M., Cochlan, W., Dennison, W.C., Dortch, Q., Gobler, C.J., Heil, C.A., Humphries, E., Lewitus, A., Magnien, R., Marshall, H.G., Sellner, K., Stockwell, D.A., Stoecker, D.K., Suddleson, M., 2008. Eutrophication and harmful algal blooms: A scientific consensus. Harmful Algae 8(1), 3-13.

Hu, H.H., Chen, W.D., Shi, Y.J., Cong, W., 2006a. Nitrate and phosphate supplementation to increase toxin production by the marine dinoflagellate Alexandrium tamarense. Mar. Pollut. Bull. 52(7), 756-760. 
Hu, H.H., Shi, Y.J., Cong, W., 2006b. Improvement in growth and toxin production of Alexandrium tamarense by two-step culture method. J. Appl. Phycol. 18(2), 119-126.

Hwang, D.F., Lu, Y.H., 2000. Influence of environmental and nutritional factors on growth, toxicity, and toxin profile of dinoflagellate Alexandrium minutum. Toxicon 38(11), 1491-1503.

James, K.J., Furey, A., Lehane, M., Ramstad, H., Aune, T., Hovgaard, P., Morris, S., Higman, W., Satake, M., Yasumoto, T., 2002. First evidence of an extensive northern European distribution of azaspiracid poisoning (AZP) toxins in shellfish. Toxicon 40(7), 909915.

Jauffrais, T., Herrenknecht, C., Séchet, V., Sibat, M., Tillmann, U., Krock, B., Kilcoyne, J., Miles, C.O., McCarron, P., Amzil, Z., Hess, P., 2012a. Quantitative analysis of azaspiracids in Azadinium spinosum cultures. Anal. Bioanal. Chem. 403(3), 833-846.

Jauffrais, T., Kilcoyne, J., Sechet, V., Herrenknecht, C., Truquet, P., Herve, F., Berard, J.B., Nulty, C., Taylor, S., Tillmann, U., Miles, C.O., Hess, P., 2012b. Production and isolation of azaspiracid-1 and -2 from Azadinium spinosum culture in pilot scale photobioreactors. Mar. Drugs 10(6), 1360-1382.

Jauffrais, T., Marcaillou, C., Herrenknecht, C., Truquet, P., Séchet, V., Nicolau, E., Tillmann, U., Hess, P., 2012c. Azaspiracid accumulation, detoxification and biotransformation in blue mussels (Mytilus edulis) experimentally fed Azadinium spinosum. Toxicon 60(4), 582-595.

John, E.H., Flynn, K.J., 2000. Growth dynamics and toxicity of Alexandrium fundyense (Dinophyceae): the effect of changing $N$ : $P$ supply ratios on internal toxin and nutrient levels. Eur. J. Phycol. 35(1), 11-23.

Keller, M.D., Selvin, R.C., Claus, W., Guillard, R.R.L., 1987. Media for the culture of oceanic ultraphytoplankton. J. Phycol. 23(4), 633-638.

Kim, C.H., Sako, Y., Ishida, Y., 1993. Variation of toxin production and composition in axenic cultures of Alexandrium catenella and A. tamarense. Nippon Suisan Gakkaishi 59, 633-639.

Klontz, K.C., Abraham, A., Plakas, S.M., Dickey, R.W., 2009. Mussel-associated azaspiracid intoxication in the United States. Ann. Intern. Med. 150, 361.

Krock, B., Tillmann, U., John, U., Cembella, A., 2008. LC-MS-MS aboard ship: tandem mass spectrometry in the search for phycotoxins and novel toxigenic plankton from the North Sea. Anal. Bioanal. Chem. 392(5), 797-803.

Krock, B., Tillmann, U., Voß, D., Koch, B.P., Salas, R., Witt, M., Potvin, É., Jeong, H.J., 2012. New azaspiracids in Amphidomataceae (Dinophyceae). Toxicon 60(5), 830-839.

Lartigue, J., Jester, E.L.E., Dickey, R.W., Villareal, T.A., 2009. Nitrogen source effects on the growth and toxicity of two strains of the ciguatera-causing dinoflagellate Gambierdiscus toxicus. Harmful Algae 8(5), 781-791.

Leong, S.C.Y., Taguchi, S., 2004. Response of the dinoflagellate Alexandrium tamarense to a range of nitrogen sources and concentrations: growth rate, chemical carbon and nitrogen, and pigments. Hydrobiologia 515(1-3), 215-224.

Lopez-Rivera, A., O'Callaghan, K., Moriarty, M., O'Driscoll, D., Hamilton, B., Lehane, M., James, K.J., Furey, A., 2009. First evidence of azaspiracids (AZAs): A family of lipophilic polyether marine toxins in scallops (Argopecten purpuratus) and mussels (Mytilus chilensis) collected in two regions of Chile. Toxicon 55(4), 692-701. 
Maclean, C., Cembella, A.D., Quilliam, M.A., 2003. Effects of light, salinity and inorganic nitrogen on cell growth and spirolide production in the marine dinoflagellate Alexandrium ostenfeldii (Paulsen) Balech et Tangen. Botanica Marina 46(5), 466-476.

Magdalena, A.B., Lehane, M., Krys, S., Fernandez, M.L., Furey, A., James, K.J., 2003. The first identification of azaspiracids in shellfish from France and Spain. Toxicon 42(1), 105-108.

McLachlan, J.L., Marr, J.C., Conlon-Kelly, A., Adamson, A., 1994. Effects of nitrogen concentration and cold temperature on DSP-toxin concentrations in the dinoflagellate Prorocentrum lima (Prorocentrales, Dinophyceace). Nat. Toxins 2, 263-270.

McMahon, T., Silke, J., 1996. West coast of Ireland winter toxicity of unknown aetiology in mussels. Harmful Algae News 14, 2.

Morlaix, M., Lassus, P., 1992. Nitrogen and phosphorus effects upon division rate and toxicity of Prorocentrum lima (Ehrenberg) Dodge. Cryptogamie Algologie 13(3), 187-195.

Morton, S.L., Bomber, J.W., 1994. Maximizing okadaic acid content from Prorocentrum hoffmannianum Faust. J. Appl. Phycol. 6, 41-44.

Morton, S.L., Bomber, J.W., Tindall, P.M., 1994. Environmental effects on the production of okadaic acid from Prorocentrum hoffmanniaum Faust .1. Temperature, light, salinity J. Exp. Mar. Biol. Ecol. 178(1), 67-77.

Navarro, J.M., Munoz, M.G., Contreras, A.M., 2006. Temperature as a factor regulating growth and toxin content in the dinofiagellate Alexandrium catenella. Harmful Algae 5(6), 762-769.

Nicolaou, K.C., Koftis, T.V., Vyskocil, S., Petrovic, G., Tang, W.J., Frederick, M.O., Chen, D.Y.K., Li, Y.W., Ling, T.T., Yamada, Y.M.A., 2006. Total synthesis and structural elucidation of azaspiracid-1. Final assignment and total synthesis of the correct structure of azaspiracid1. J. Am. Chem. Soc. 128(9), 2859-2872.

Ogata, T., Ishimaru, T., Kodama, M., 1987. Effect of water temperature and light intensity on growth rate and toxicity change in Protogonyaulax tamarensis Mar. Biol. 95(2), 217-220.

Pan, Y., Cembella, A.D., Quilliam, M.A., 1999. Cell cycle and toxin production in the benthic dinoflagellate Prorocentrum lima. Mar. Biol. 134(3), 541-549.

Parkhill, J.P., Cembella, A.D., 1999. Effects of salinity, light and inorganic nitrogen on growth and toxigenicity of the marine dinoflagellate Alexandrium tamarense from northeastern Canada. J. Plankton Res. 21(5), 939-955.

Pollingher, U., Zemel, E., 1981. Insitu and experiemental evidence of the influence of turbulence on cell division processes of Peridinium cinctum Forma Westii (lemm) Lefevre $\mathrm{Br}$. Phycological J. 16(3), 281-287.

Potvin, E., Jeong, H.J., Kang, N.S., Tillmann, U., Krock, B., 2012. First report of the photosynthetic dinoflagellate genus Azadinium in the Pacific Ocean: morphology and molecular characterization of Azadinium cf. poporum. J. Eukaryot. Microbiol. 59(2), 145-156.

Rost, B., Richter, K.U., Riebesell, U., Hansen, P.J., 2006. Inorganic carbon acquisition in red tide dinoflagellates. Plant Cell Envi 29(5), 810-822. 
Salas, R., Tillmann, U., John, U., Kilcoyne, J., Burson, A., Cantwell, C., Hess, P., Jauffrais, T., Silke, J., 2011. The role of Azadinium spinosum (Dinophyceae) in the production of azaspiracid shellfish poisoning in mussels. Harmful Algae 10(6), 774-783.

Satake, M., Ofuji, K., Naoki, H., James, K.J., Furey, A., McMahon, T., Silke, J., Yasumoto, T., 1998. Azaspiracid, a new marine toxin having unique spiro ring assemblies, isolated from Irish mussels, Mytilus edulis. J. Am. Chem. Soc. 120(38), 9967-9968.

Sullivan, J.M., Swift, E., 2003. Effects of small-scale turbulence on net growth rate and size of ten species of marine dinoflagellates. J. Phycol. 39(1), 83-94.

Taleb, H., Vale, P., Amanhir, R., Benhadouch, A., Sagou, R., Chafik, A., 2006. First detection of azaspiracids in mussels in north west Africa. J. Shellfish Res. 25(3), 1067-1070.

Tillmann, U., Elbrachter, M., John, U., Krock, B., 2011. A new non-toxic species in the dinoflagellate genus Azadinium: A. poporum sp. nov. Eur. J. Phycol. 46(1), 74-87.

Tillmann, U., Elbrachter, M., John, U., Krock, B., Cembella, A., 2010. Azadinium obesum (Dinophyceae), a new nontoxic species in the genus that can produce azaspiracid toxins. Phycologia 49(2), 169-182.

Tillmann, U., Elbrachter, M., Krock, B., John, U., Cembella, A., 2009. Azadinium spinosum gen. et sp. nov. (Dinophyceae) identified as a primary producer of azaspiracid toxins. Eur. J. Phycol. 44(1), 63-79.

Tillmann, U., Salas, R., Gottschling, M., Krock, B., O'Driscoll, D., Elbrächter, M., 2012a. Amphidoma languida sp. nov. (Dinophyceae) reveals a close relationship between Amphidoma and Azadinium. Protist 163(5), 701-719.

Tillmann, U., Soehner, S., Nézan, E., Krock, B., 2012b. First record of the genus Azadinium (Dinophyceae) from the Shetland Islands, including the description of Azadinium polongum sp. nov. Harmful Algae(in press).

Ueoka, R., Ito, A., Izumikawa, M., Maeda, S., Takagi, M., Shin-Ya, K., Yoshida, M., van Soest, R.W.M., Matsunaga, S., 2009. Isolation of azaspiracid-2 from a marine sponge Echinoclathria sp. as a potent cytotoxin. Toxicon 53(6), 680-684.

Vale, P., Bire, R., Hess, P., 2008. Confirmation by LC-MS/MS of azaspiracids in shellfish from the Portuguese north-western coast. Toxicon 51(8), 1449-1456.

Vanucci, S., Guerrini, F., Milandri, A., Pistocchi, R., 2010. Effects of different levels of N- and P-deficiency on cell yield, okadaic acid, DTX-1, protein and carbohydrate dynamics in the benthic dinoflagellate Prorocentrum lima. Harmful Algae 9(6), 590-599.

Vanucci, S., Pezzolesi, L., Pistocchi, R., Ciminiello, P., Dell'Aversano, C., Dello lacovo, E., Fattorusso, E., Tartaglione, L., Guerrini, F., 2012. Nitrogen and phosphorus limitation effects on cell growth, biovolume, and toxin production in Ostreopsis cf. ovata. Harmful Algae 15, 78-90.

Xu, N., Duan, S.S., Li, A.F., Zhang, C.W., Cai, Z.P., Hu, Z.X., 2010. Effects of temperature, salinity and irradiance on the growth of the harmful dinoflagellate Prorocentrum donghaiense Lu. Harmful Algae 9(1), 13-17.

Yao, J., Tan, Z., Zhou, D., Guo, M., Xing, L., Yang, S., 2010. Determination of azaspiracid-1 in shellfishes by liquid chromatography with tandem mass spectrometry. Chinese journal of chromatography 28(4), 363-367. 
Table 1. Batch culture: $A$. spinosum specific growth rate, $\mu\left(d^{-1}\right)$, maximum cell concentration, Cmax $\left(10^{3}\right.$ cell $\left.\mathrm{mL}^{-1}\right)$, AZA cell quota $\left(\mathrm{fg}\right.$ cell $\left.{ }^{-1}\right)$ and and ESD (mean estimated spherical diameter $(\mu \mathrm{m}))$ in batch culture at different salinities, photon flux densities (PFD, $\mu \mathrm{mol} \mathrm{m} \mathrm{m}^{-2} \mathrm{~s}^{-1}$ ), temperatures $\left({ }^{\circ} \mathrm{C}\right)$ and with the presence or absence of aeration (values with different letters are statistically different at $P<0.05)$. Standard batch culture conditions were applied for all conditions unless specified in a given treatment $(n=3)$.

\begin{tabular}{llcccc}
$\begin{array}{l}\text { Environmental } \\
\text { factors }\end{array}$ & $\begin{array}{c}\mu^{*} \\
\left(\mathrm{~d}^{-1}\right)\end{array}$ & $\begin{array}{c}\text { Cmax } \\
\left(10^{3} \text { cell mL }^{-1}\right)\end{array}$ & $\begin{array}{c}\text { AZAs } \\
\left(\mathrm{fg} \mathrm{cell}^{-1}\right)\end{array}$ & $\begin{array}{c}\mathrm{ESD}^{\S} \\
(\mu \mathrm{m})\end{array}$ \\
\hline Temperature & 10 & $0.12 \pm 0.01^{\mathrm{e}}$ & $53 \pm 5^{\mathrm{d}}$ & $220 \pm 38^{\mathrm{a}}$ & $10.8 \pm 0.5^{\mathrm{a}}$ \\
$\left({ }^{\circ} \mathrm{C}\right)$ & 14 & $0.25 \pm 0.01^{\mathrm{d}}$ & $80 \pm 2^{\mathrm{c}}$ & $80 \pm 10^{\mathrm{b}}$ & $10.2 \pm 0.4^{\mathrm{b}}$ \\
& 18 & $0.33 \pm 0.03^{\mathrm{c}}$ & $86 \pm 7^{\mathrm{bc}}$ & $14 \pm 2^{\mathrm{c}}$ & $9.4 \pm 0.2^{\mathrm{c}}$ \\
& 22 & $0.46 \pm 0.03^{\mathrm{a}}$ & $90 \pm 5^{\mathrm{a}}$ & $8 \pm 1^{\mathrm{d}}$ & $9.1 \pm 0.3^{\mathrm{c}}$ \\
& 26 & $0.40 \pm 0.02^{\mathrm{b}}$ & $58 \pm 7^{\mathrm{d}}$ & $14 \pm 1^{\mathrm{c}}$ & $9.2 \pm 0.2^{\mathrm{c}}$ \\
\hline Salinity & 30 & $0.26 \pm 0.01^{\mathrm{b}}$ & $48 \pm 1^{\mathrm{c}}$ & $31 \pm 2^{\mathrm{b}}$ & $8.9 \pm 0.2^{\mathrm{b}}$ \\
& 32 & $0.33 \pm 0.00^{\mathrm{a}}$ & $65 \pm 2^{\mathrm{b}}$ & $29 \pm 3^{\mathrm{b}}$ & $9.2 \pm 0.3^{\mathrm{ab}}$ \\
& 35 & $0.34 \pm 0.00^{\mathrm{a}}$ & $77 \pm 3^{\mathrm{a}}$ & $23 \pm 1^{\mathrm{c}}$ & $9.3 \pm 0.4^{\mathrm{ab}}$ \\
& 40 & $0.22 \pm 0.01^{\mathrm{c}}$ & $32 \pm 2^{\mathrm{d}}$ & $37 \pm 3^{\mathrm{a}}$ & $9.8 \pm 0.6^{\mathrm{a}}$ \\
\hline PFD & 50 & $0.31 \pm 0.01^{\mathrm{c}}$ & $95 \pm 7$ & $16 \pm 2$ & $9.5 \pm 0.4$ \\
$\left(\mu \mathrm{mol} \mathrm{m}{ }^{-2} \mathrm{~s}^{-1}\right)$ & 100 & $0.42 \pm 0.01^{\mathrm{b}}$ & $94 \pm 2$ & $22 \pm 1$ & $9.9 \pm 0.3$ \\
& 150 & $0.41 \pm 0.01^{\mathrm{b}}$ & $95 \pm 2$ & $16 \pm 4$ & $9.7 \pm 0.4$ \\
& 200 & $0.41 \pm 0.01^{\mathrm{b}}$ & $94 \pm 3$ & $16 \pm 1$ & $9.8 \pm 0.4$ \\
& 250 & $0.41 \pm 0.02^{\mathrm{b}}$ & $98 \pm 1$ & $21 \pm 1$ & $9.7 \pm 0.3$ \\
\hline Aeration & Yes & $0.41 \pm 0.02^{\mathrm{b}}$ & $316 \pm 15^{\mathrm{a}}$ & $122 \pm 2^{\mathrm{a}}$ & $9.5 \pm 0.2$ \\
& No & $0.66 \pm 0.02^{\mathrm{a}}$ & $90 \pm 2^{\mathrm{b}}$ & $15 \pm 2^{\mathrm{b}}$ & $9.3 \pm 0.4$ \\
\hline
\end{tabular}

* calculated between the initial cell density the day represented by a star $(*)$ in the different graphics

$\S$ mean ESD over the experiment 
Table 2. Continuous culture: $A$. spinosum concentration $\left(10^{3}\right.$ cell $\left.\mathrm{mL}^{-1}\right)$, mean estimated spherical diameter (ESD, $\mu \mathrm{m})$, cellular volume $\left(\mu \mathrm{m}^{3} \mathrm{~mL}^{-1}\right)$ and AZA cell quota $(A Z A 1+2$ $\left.\mathrm{fg} \mathrm{cell}^{-1}\right)$ in continuous culture at steady state using different photon flux densities (PFD, $\mu \mathrm{mol} \mathrm{m} \mathrm{m}^{-2} \mathrm{~s}^{-1}$ ), $\mathrm{K}$ medium concentration, nitrogen sources (nitrate and urea) and N/P ratios (values with different letters are statistically different at $\mathrm{P}<0.05$ ). Standard continuous culture conditions were applied for all conditions unless specified in a given treatment (nine sampling occasions for each of the two bioreactors).

\begin{tabular}{llcccc} 
Factors & $\begin{array}{c}\text { Concentration } \\
\left(10^{3} \text { cell mL }^{-1}\right)\end{array}$ & $\begin{array}{c}\text { ESD } \\
(\mu \mathrm{m})\end{array}$ & $\begin{array}{c}\text { Biovolume } \\
\left(10^{6} \mu \mathrm{m}^{3} \mathrm{~mL}^{-1}\right)\end{array}$ & $\begin{array}{c}\text { AZAs } \\
\left(\mathrm{fg} \mathrm{cell}^{-1}\right)\end{array}$ \\
\hline PFD $\left(\mu \mathrm{mol} \mathrm{m}^{-2} \mathrm{~s}^{-1}\right)$ & 100 & $185 \pm 7^{\mathrm{b}}$ & $9.5 \pm 0.1^{\mathrm{c}}$ & $85 \pm 3^{\mathrm{c}}$ & $21 \pm 2^{\mathrm{b}}$ \\
$\mu=0.2$ day $^{-1}$ & 200 & $194 \pm 5^{\mathrm{a}}$ & $9.9 \pm 0.1^{\mathrm{b}}$ & $101 \pm 3^{\mathrm{b}}$ & $58 \pm 9^{\mathrm{a}}$ \\
& 400 & $195 \pm 7^{\mathrm{a}}$ & $10.1 \pm 0.1^{\mathrm{a}}$ & $108 \pm 4^{\mathrm{a}}$ & $69 \pm 11^{\mathrm{a}}$ \\
\hline $\mathrm{Kmod}$ & 0.5 & $122 \pm 7^{\mathrm{c}}$ & $10.1 \pm 0.1^{\mathrm{a}}$ & $66 \pm 3^{\mathrm{c}}$ & $58 \pm 5^{\mathrm{a}}$ \\
$\mu=0.2$ day $^{-1}$ & 1 & $196 \pm 7^{\mathrm{b}}$ & $9.9 \pm 0.1^{\mathrm{a}}$ & $104 \pm 3^{\mathrm{b}}$ & $47 \pm 6^{\mathrm{b}}$ \\
& 2 & $246 \pm 29^{\mathrm{a}}$ & $9.7 \pm 0.2^{\mathrm{b}}$ & $170 \pm 17^{\mathrm{a}}$ & $25 \pm 7^{\mathrm{c}}$ \\
\hline Nitrogen source & Nitrate $(882 \mu \mathrm{M})$ & $207 \pm 13^{\mathrm{a}}$ & $10.2 \pm 0.2^{\mathrm{a}}$ & $119 \pm 8^{\mathrm{a}}$ & $41 \pm 8$ \\
$\mu=0.3$ day $^{-1}$ & Urea $(100 \mu \mathrm{M})$ & $182 \pm 10^{\mathrm{b}}$ & $9.9 \pm 0.1^{\mathrm{b}}$ & $95 \pm 7^{\mathrm{b}}$ & $42 \pm 6$ \\
\hline $\mathrm{NO}_{3}{ }^{-} / \mathrm{PO}_{4}{ }^{3-}$ & $40 / 5$ & $59 \pm 6^{\mathrm{c}}$ & $9.6 \pm 0.3^{\mathrm{b}}$ & $29 \pm 4^{\mathrm{c}}$ & $18 \pm 3^{\mathrm{b}}$ \\
ratio $(\mu \mathrm{M})$ & $160 / 10$ & $187 \pm 11^{\mathrm{b}}$ & $9.7 \pm 0.1^{\mathrm{ab}}$ & $92 \pm 4^{\mathrm{b}}$ & $14 \pm 1^{\mathrm{b}}$ \\
$\mu=0.3$ day $^{-1}$ & $882 / 10$ & $216 \pm 10^{\mathrm{a}}$ & $10.0 \pm 0.3^{\mathrm{a}}$ & $117 \pm 6^{\mathrm{a}}$ & $36 \pm 2^{\mathrm{a}}$ \\
\hline
\end{tabular}

Table 3. A. spinosum specific growth rate, $\mu\left(\mathrm{d}^{-1}\right)$, maximum cell concentration, $\mathrm{Cmax}\left(10^{3}\right.$ cell $\left.\mathrm{mL}^{-1}\right), A Z A$ cell quota $\left(A Z A 1+2 \mathrm{fg} \mathrm{cell}^{-1}\right)$ and ESD (mean estimated spherical diameter $(\mu \mathrm{m}))$ in batch culture using different culture medium and phosphate sources (values with different letters are statistically different at $P<0.05$ ). Standard batch culture conditions were applied for all conditions unless specified in a given treatment $(n=3)$.

\begin{tabular}{|c|c|c|c|c|c|}
\hline \multicolumn{2}{|c|}{ Nutritional factors } & $\begin{array}{l}\mu^{*} \\
\left(d^{-1}\right)\end{array}$ & $\begin{array}{c}\text { Cmax } \\
\left(10^{3} \text { cell } \mathrm{mL}^{-1}\right)\end{array}$ & $\begin{array}{c}\text { AZAs } \\
\left(\text { fg cell }^{-1}\right)\end{array}$ & $\begin{array}{l}\mathrm{ESD}^{\S} \\
(\mu \mathrm{m})\end{array}$ \\
\hline Culture & Kmod & $0.45 \pm 0.004^{\mathrm{a}}$ & $98 \pm 3$ & $20 \pm 2^{b}$ & $9.5 \pm 0.1^{\mathrm{a}}$ \\
\hline \multirow[t]{3}{*}{ medium } & Kmod2 & $0.39 \pm 0.006^{\mathrm{c}}$ & $88 \pm 1$ & $27 \pm 1^{\mathrm{a}}$ & $9.3 \pm 0.1^{\mathrm{a}}$ \\
\hline & L1 & $0.40 \pm 0.004^{\mathrm{c}}$ & $101 \pm 1$ & $22 \pm 1^{b}$ & $8.9 \pm 0.2^{b}$ \\
\hline & $\mathrm{L} 1+\mathrm{SE}$ & $0.42 \pm 0.001^{\mathrm{b}}$ & $100 \pm 3$ & $14 \pm 4^{b}$ & $8.9 \pm 0.2^{\mathrm{b}}$ \\
\hline \multirow[t]{2}{*}{ Phosphate } & $\mathrm{NaH}_{2} \mathrm{PO}_{4}$ & $0.40 \pm 0.01$ & $78 \pm 1$ & $17 \pm 1^{\mathrm{b}}$ & $10.1 \pm 0.5$ \\
\hline & $\beta$ glycerophosphate & $0.42 \pm 0.02$ & $81 \pm 1$ & $24 \pm 1^{\mathrm{a}}$ & $9.9 \pm 0.2$ \\
\hline
\end{tabular}


Table 4. A. spinosum specific growth rate, $\mu\left(\mathrm{d}^{-1}\right)$, maximum cell concentration, Cmax $\left(10^{3}\right.$ cell $\left.\mathrm{mL}^{-1}\right), A Z A$ cell quota $\left(A Z A 1+2 \mathrm{fg} \mathrm{cell}^{-1}\right)$ in batch culture using different source of nitrogen (Nitrate, ammonium and urea at the indicated concentration in the table). Standard batch culture conditions were applied for all conditions unless specified in a given treatment $(n=2)$.

\begin{tabular}{ccccccc}
$\mathrm{NO}_{3}{ }^{-}$ & $\mathrm{NH}_{4}{ }^{2+}$ & $\begin{array}{c}\mathrm{Urea} \\
(\mu \mathrm{M})\end{array}$ & $\begin{array}{c}\mu * \\
(\mu \mathrm{M})\end{array}$ & $\begin{array}{c}\mathrm{Cmax}) \\
\left(\mathrm{d}^{-1}\right)\end{array}$ & $\begin{array}{c}\mathrm{AZAs}^{3} \text { cell mL } \\
\left(10^{3}\right) \\
\left(\mathrm{fg} \mathrm{cell}^{-1}\right)\end{array}$ & $\begin{array}{c}\mathrm{ESD}^{\S} \\
(\mu \mathrm{m})\end{array}$ \\
\hline 50 & 0 & 0 & $0.39 \pm 0.01$ & $95 \pm 1$ & $17.3 \pm 0.1$ & $9.6 \pm 0.1$ \\
50 & 100 & 0 & $0.28 \pm 0.01$ & $101 \pm 2$ & $10.1 \pm 0.1$ & $10.2 \pm 0.1$ \\
50 & 0 & 100 & $0.40 \pm 0.01$ & $95 \pm 1$ & $12.3 \pm 0.8$ & $9.6 \pm 0.1$ \\
50 & 100 & 100 & $0.27 \pm 0.01$ & $109 \pm 9$ & $11.3 \pm 0.8$ & $10.3 \pm 0.1$ \\
\hline
\end{tabular}

* calculated between the initial cell density the day represented by a star $(*)$ in the graphic

$\S$ mean ESD over the experiment

Table 5. A. spinosum AZA1+2 cell quota $\left(\mathrm{fg}\right.$ cell $\left.^{-1}\right)$, estimated cell volume $\left(\mu \mathrm{m}^{3}\right)$, number of cell divisions, time for one cell division $(h)$, time of light for one cell division $(h)$ and $A Z A 1+2$ expressed in $\mathrm{fg} \mathrm{cell}^{-1} \mathrm{~h}^{-1}$ of light and in $\mathrm{fg} \mu \mathrm{m}^{-3} \mathrm{~h}^{-1}$ of light observed and estimated at 10,14 , 18,22 and $26^{\circ} \mathrm{C}$, and the calculated ratio between the values found at $10^{\circ} \mathrm{C}$ and $22^{\circ} \mathrm{C}$.

\begin{tabular}{|c|c|c|c|c|c|c|}
\hline & $10^{\circ} \mathrm{C}$ & $14^{\circ} \mathrm{C}$ & $18^{\circ} \mathrm{C}$ & $22^{\circ} \mathrm{C}$ & $26^{\circ} \mathrm{C}$ & $\begin{array}{c}\text { ratio } \\
10^{\circ} \mathrm{C} / 22^{\circ} \mathrm{C}\end{array}$ \\
\hline AZA1+2 (fg cell $\left.{ }^{-1}\right)$ & $220 \pm 38$ & $80 \pm 10$ & $14 \pm 2$ & $8 \pm 1$ & $14 \pm 1$ & 27.5 \\
\hline Estimated cell volume $\left(\mu \mathrm{m}^{3}\right)^{*}$ & 650 & 561 & 439 & 392 & 410 & 1.7 \\
\hline Number of cell division ${ }^{\S}$ & 3.1 & 3.1 & 3.6 & 3.9 & 3.5 & 0.8 \\
\hline Time for one cell division ${ }^{\S \S}(\mathrm{h})$ & 348 & 166 & 163 & 108 & 119 & 3.2 \\
\hline Time of light for 1 cell division (h) & 232 & 111 & 108 & 72 & 80 & 3.2 \\
\hline AZA $1+2\left(\right.$ fg cell $^{-1} \mathrm{~h}^{-1}$ of light $)$ & 0.9 & 0.7 & 0.1 & 0.1 & 0.2 & 8.5 \\
\hline AZA1 +2 (fg $\mu \mathrm{m}^{-3} \mathrm{~h}^{-1}$ of light) & 0.0015 & 0.0013 & 0.0003 & 0.0003 & 0.0004 & 5.1 \\
\hline
\end{tabular}

* Estimated cell volume $=4 / 3 \times \pi \times(\mathrm{ESD} / 2)^{3}$

${ }^{\S}$ Number of cell division from the beginning of the experiment until AZA analysis

$\S \S$ Average time for one cell division from the beginning of the experiment until AZA analysis 
Figure 1. Growth kinetics for the different condition of $(A)$ temperature (10 to $\left.26^{\circ} \mathrm{C}\right)$, (B) salinity (30 to 40), (C) photon flux density (50 to $250 \mu \mathrm{mol} \mathrm{m} \mathrm{m}^{-2} \mathrm{~s}^{-1}$ ) and (D) aeration (with and without), arrows indicate at which day samples were taken for AZA analysis and * the day used to calculate growth rates.
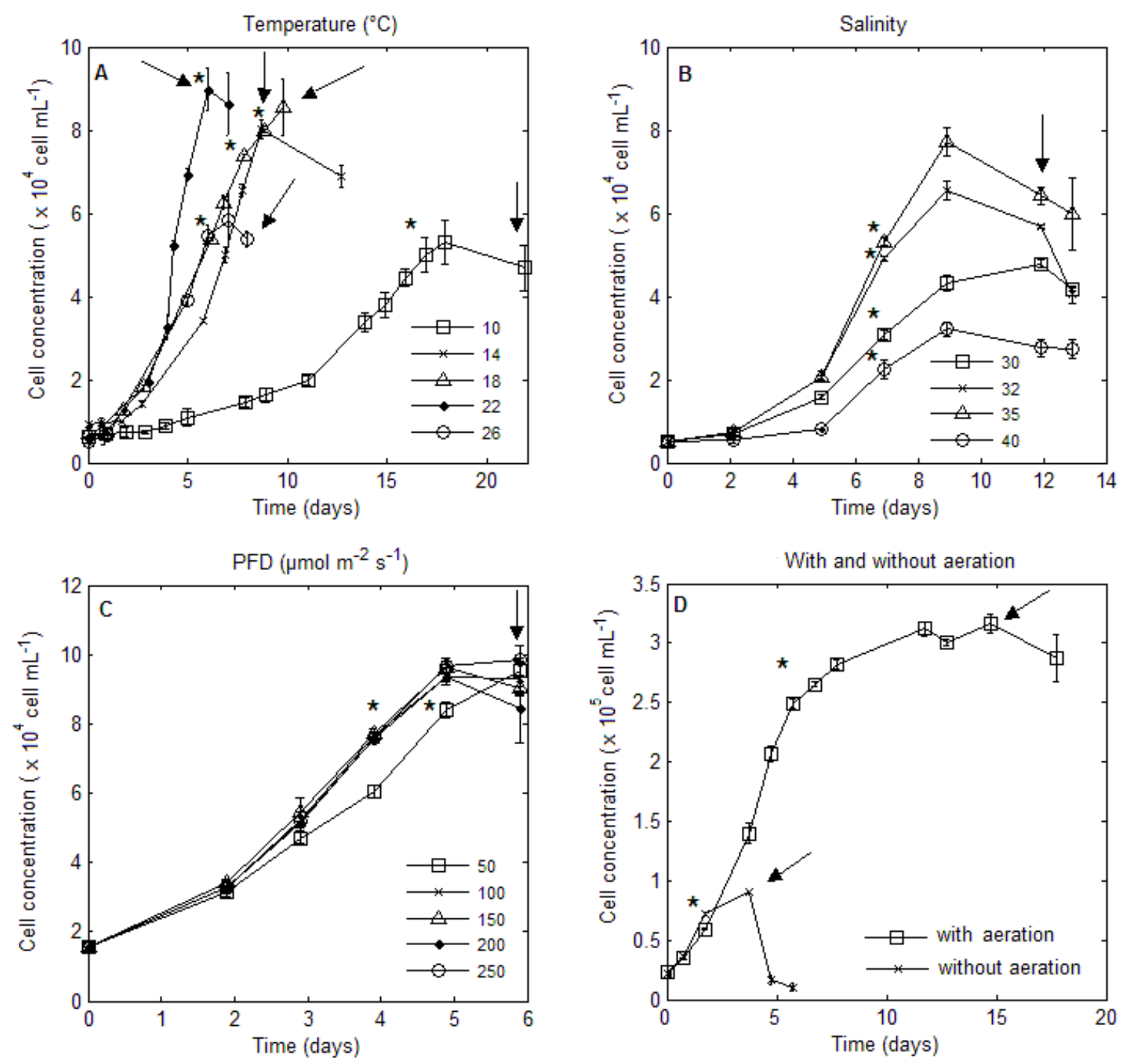
Figure 2. (A) A. spinosum cell concentration and mean spherical diameter (ESD) as a function of time in aerated $10 \mathrm{~L}$ culture flasks, (B) Gompertz model fitted to the cell concentration with its $95 \%$ confident bounds for the maximum cell concentration (Cmax), growth rate ( $\mu$ max), latency time and its adjusted $\mathrm{R}^{2},(\mathrm{C}) \mathrm{NO}_{3}{ }^{-}$and $\mathrm{PO}^{3-}$ consumption by $A$. spinosum as a function of time and (D) AZA1+2 cell quota as a function of time (error bars $=$ $\mathrm{SD}, \mathrm{n}=3)$.
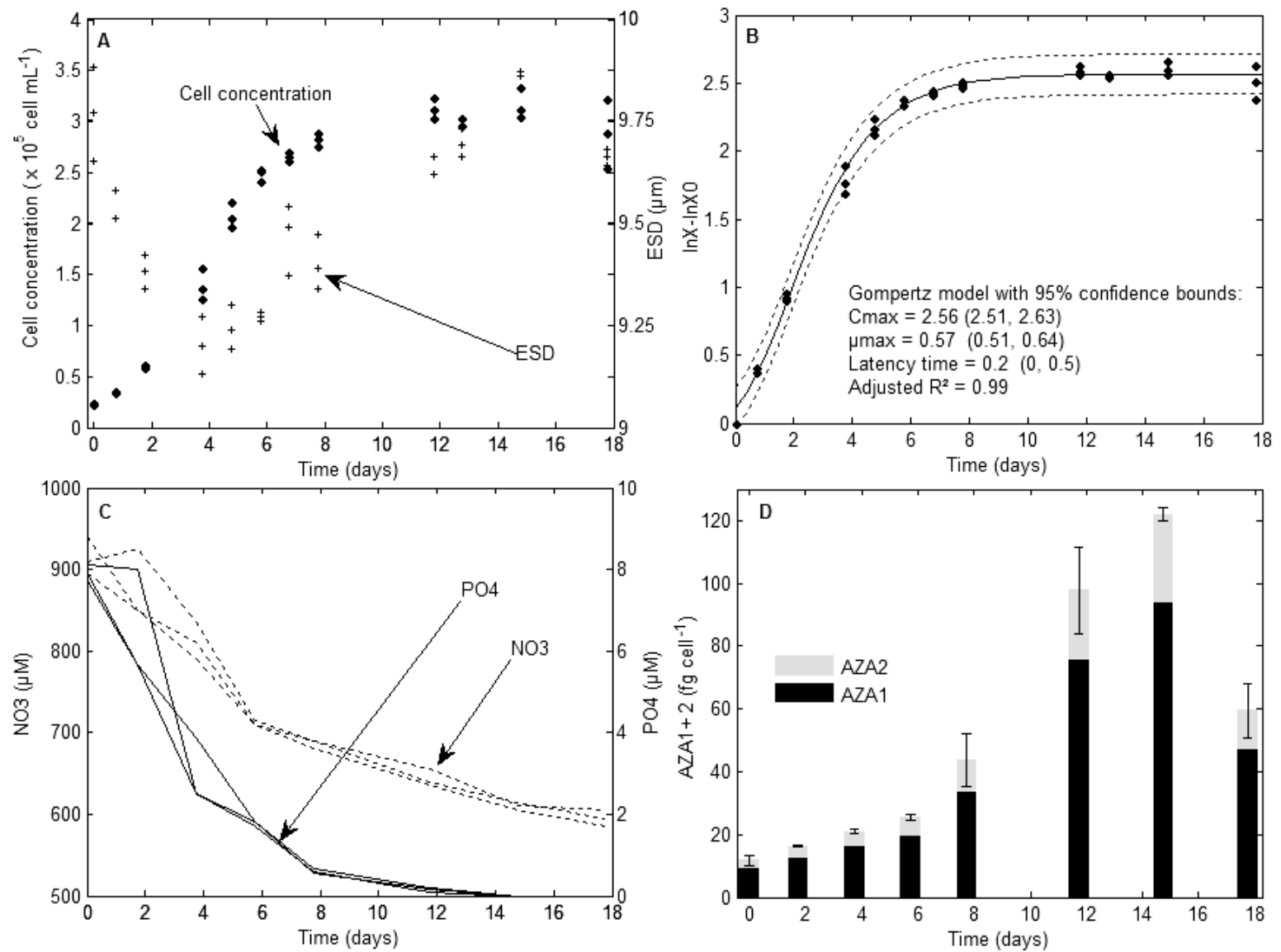
Figure 3. A. spinosun concentration (cell $\mathrm{mL}^{-1}$ ) and cellular volume $\left(\mu \mathrm{m}^{3} \mathrm{~mL}^{-1}\right)$ kinetics in $100 \mathrm{~L}$ photobioreactors at a dilution rate of 0.2 day $^{-1}$ and at three different irradiance conditions 100,200 and $400 \mu \mathrm{mol} \mathrm{m} \mathrm{m}^{-2}$. The steady states are represented by the red lines and the arrows represent the day where the irradiance was changed.

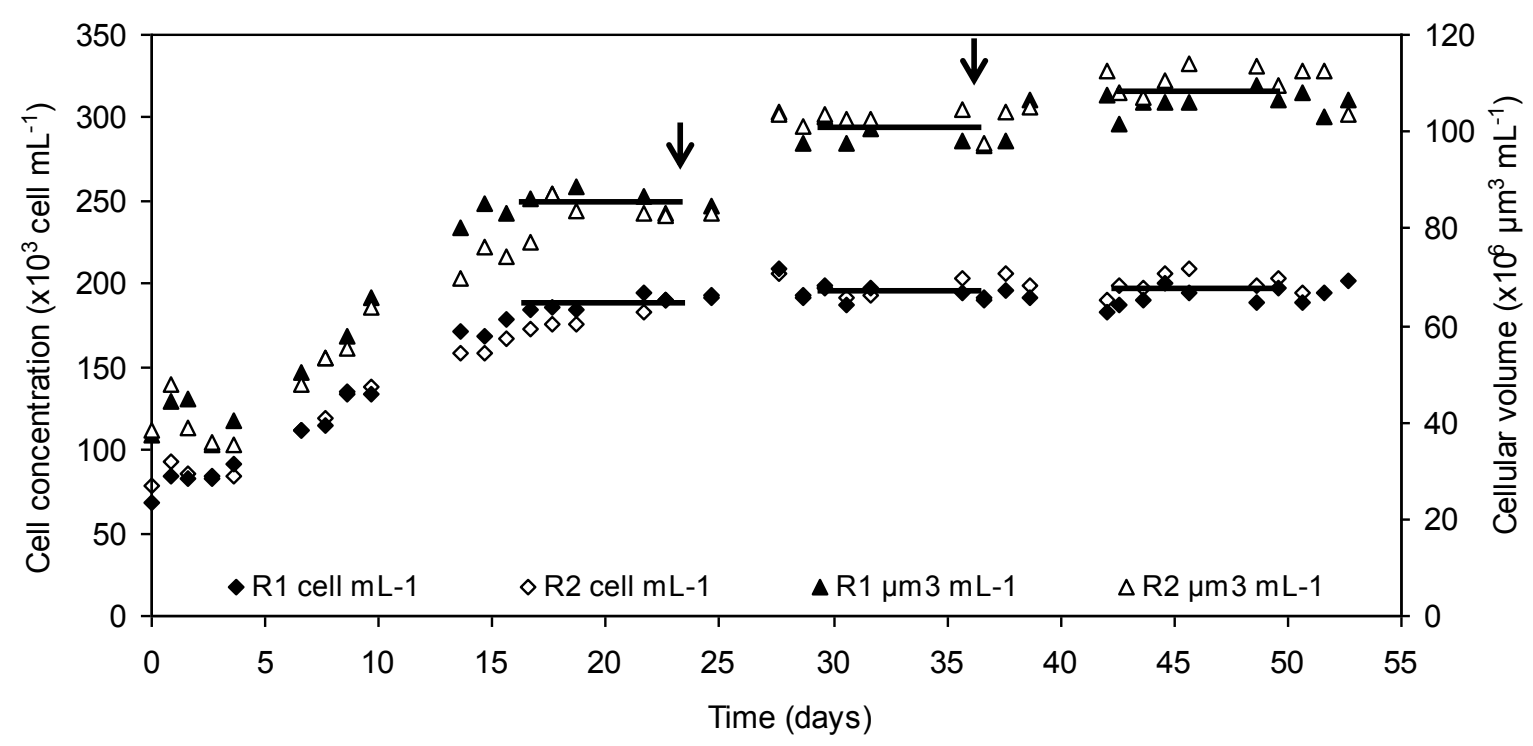

Figure 4. Growth kinetics for the different condition culture medium tested (Kmod1, Kmod2, $L 1, L 1+S E)$, arrows indicate at which day samples were taken for AZA analysis and * the day used to calculate growth rates.

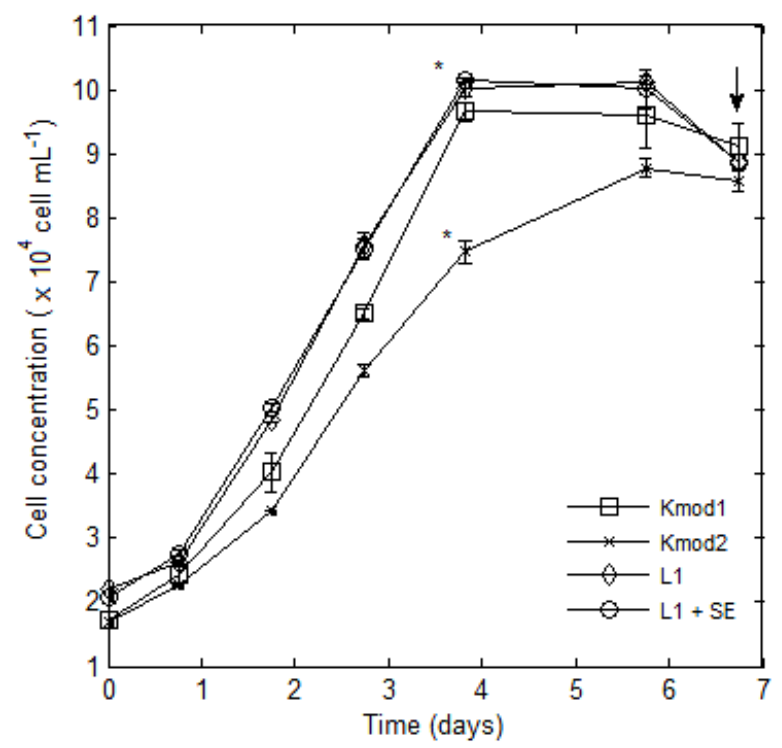


Figure 5. Effect of the addition of ammonium $\left(\mathrm{NH}_{4}{ }^{2-}\right)$ and/or urea to a medium with nitrate on growth and cell concentration (nitrate $\left(\mathrm{NO}_{3}{ }^{-}\right): 50 \mu \mathrm{M}$, ammonium and urea: $100 \mu \mathrm{M}$ ), arrows indicate at which day samples were taken for AZA analysis and * the day used to calculate growth rates

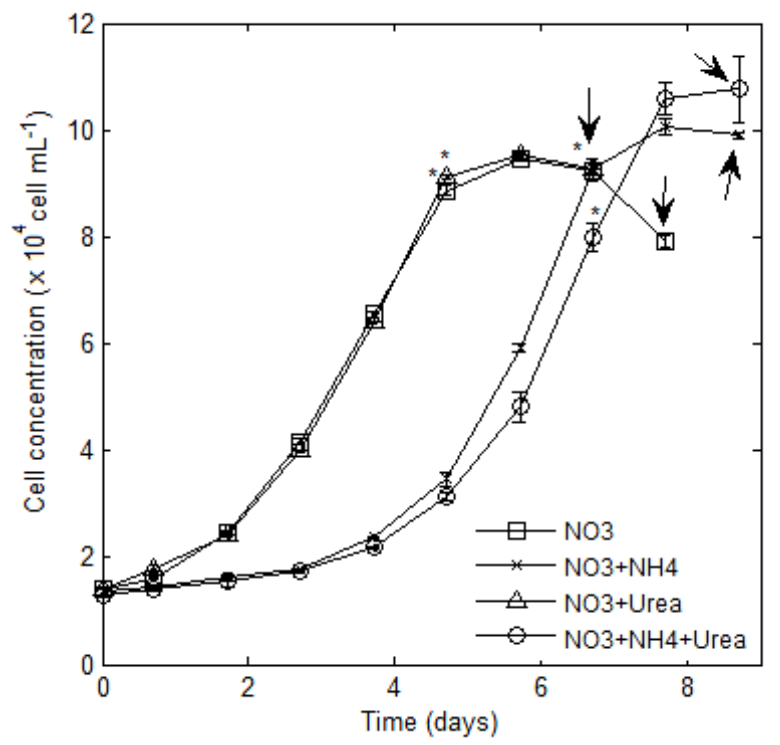

